\title{
Pharmacokinetics and bioavailability of difloxacin in camel
}

\author{
M. A. Tohamy ${ }^{1}$, A. A. M. El- Gendy ${ }^{1}$, M. Ismail ${ }^{2}$ \\ ${ }^{1}$ Pharmacology Department, Faculty of Veterinary Medicine Beni-suef University, Beni-suef, Egypt \\ ${ }^{2}$ Pharmacology Department, Faculty of Veterinary Medicine, Cairo University, Cairo, Egypt
}

\begin{abstract}
The pharmacokinetic profile of difloxacin was investigated in camels after single intravenous and intramuscular administration of $5 \mathrm{mg} \mathrm{kg}^{-1}$ b.wt. After i. v. injection, serum concentration time curve was best described as two compartment open model. The distribution and elimination half lives $\left(t_{0.5(\alpha)}\right.$ and $\left.t_{0.5(\beta)}\right)$ were $0.513 \pm 0.01 \mathrm{~h}$ and $6.3 \pm 0.15 \mathrm{~h}$. respectively. Difloxacin was distributed extravascularly with a volume of distribution $\left(\mathrm{Vd}_{\mathrm{ss}}\right) \mathbf{1 . 1 0} \pm 0.035 \mathrm{I} \mathrm{kg}^{-1}$., and total body clearance $\left(C L_{\mathrm{B}}\right)$ of $0.141+0.031 \mathrm{l} \mathrm{kg}^{-1} \mathrm{~h}^{-1}$. following intramusclar injection, peak serum concentration $\left(C_{\text {max }}\right) 2.59 \pm 0.19 \mathrm{ug} \mathrm{ml}^{-1}$ attained after $T_{\max } 3.05 \pm 0.035 \mathrm{~h}$. The absorption and elimination half lives $\quad\left(t_{0.5}\right.$ (ab) and $t_{0.5}$ (el) $)$ were $0.95 \pm 0.003$ and $5.86 \pm 0.33 \mathrm{~h}$., respectively. The systemic bioavailablility (F) and the plasma protein binding were 87.95 and $23 \%$, respectively.
\end{abstract}

Difloxacin is a member of fluoroquinolones acting through inhibiting bacterial DNA topoisomerases (gyrase) .It has an increased spectrum of activity against anaerobes, chlamydia and rickettsia (Adams, 1995).

The pharmacokinetic studies have been conducted in pig (Inui et al., 1998), dog (Frazier et al., 2000 and Heinin, 2002), goat (Atef et al., 2002) and rabbit (Abd El-Aty et al., 2005). However, there is lack of such studies in camel. The camel is a ruminant animal that has developed many physiological adaptations, especially with respect to water metabolism (Yagil, 1985, Etzion and Yagil, 1986). This adaptation may be responsible for major differences in drug disposition between camel and other ruminants. Such differences have been documented for benzyl penicillin (Oukessou et al., 1990) and sulphadimidine (Younan et al., 1989). Previous studies have been demonstrated that pharmacokinetic parameters and dosage regimens of chemotherapeutic agents should be determined in animal species to which these drugs are administrated (Baggot, 1977).

Thus the aim of the present study is to investigate the pharmacokinetic behaviour and systemic bioavilabitity of difloxacin in camel to establish dosage regimen for potential clinical use in treating camel infectious disease caused by susceptible bacteria.

\section{Material and methods}

Drug. Difloxacin hydrochloride (Dicural ${ }^{\circledR}$ ) injection, Fort Dodge Animal health, Holland, Netherlands.
Animals. Three clinically healthy one-humped camels of both sex of 550-600 kg b. wt. and 4-6 years old were used in this study. They were fed barseem, rice straw and cotton seed cake and water ad-libitum .

Experimental design. Camels were injected 5 $\mathrm{mg} \mathrm{kg}^{-1}$ b. wt. difloxacin via single i. v. and i. m. administration in cross over study with 15 days interval to ensure complete clearance of the drug. Blood samples were collected via vein puncture from jugular vein before and 5, 10, 15, 30 minutes $1,2,4,6,8,12$ and 24 hours postadministration. Blood samples were left 30 minutes to clot and then centrifuged at $3000 \mathrm{rpm}$ for 15 minutes to obtain clear serum that was kept at $-20^{\circ} \mathrm{C}$ until assayed.

Drug bioassay. Serum concentrations were detected by the microbiological assay (Bennett et al., 1966) using E. coli (ATCC 25922) as test organism and samples were assayed in triplicates. The minimal detectable limit was $0.03 \mathrm{ug} \mathrm{m}^{-1}$. The standard curve and protein binding tendency were determined in vitro using antimicrobial free camel serum and phosphate buffer saline. The difference of inhibition zone diameter between serum and buffer was used to calculate the protein binding tendency of difloxacin according to (Craig and Suh 1980) by the following equation:

Protein binding\%=

zone of inhibition of buffer- zone of inhibition of serum $\times 100$ zone of inhibition of buffer

Pharmacokinetic analysis.-Serum concentrations $\left(\log _{10}\right)$ versus time curve were generated and best fitted by the aid of computer polyexpon- 
ential curve stripping program (RSTRIP, Micromath, Scientific software, USA). The analytical model was selected by application of Akaike information criterion to minimize the residuals (Yamaoka, et al., 1978). Data from each animal were fitted individually; the pharmacokinetic variables were computed by the aid of the software program. The hybrid rate constants of distribution and elimination phase ( $\alpha$ and $\beta$ ), first order absorption and elimination rate constants $\left[\mathrm{K}_{(\mathrm{ab})}\right.$ and $\left.\mathrm{K}_{(\mathrm{el})}\right]$ and the correspondding extrapolated zero time intercepts (A and $\mathrm{B})$, absorption, distribution and elimination half lives $\left(\mathrm{t}_{0.5(\mathrm{ab}),} \mathrm{t}_{0.5(\alpha)}, \mathrm{t}_{0.5(\beta)}\right.$ and $\left.\mathrm{t}_{0.5(\mathrm{el})}\right)$, transfer rate constants $\left(\mathrm{K}_{12}\right.$ and $\left.\mathrm{K}_{21}\right)$, area under the curve from zero to infinite time $\left(\mathrm{AUC}_{0-\alpha}\right)$, mean residence time (MRT), maximum serum concentration $\left(\mathrm{C}_{\max }\right)$ and time to be achieved $\left(\mathrm{T}_{\max }\right)$ were calculated. The elimination rate constant $\left(\mathrm{K}_{10}\right)$, volume of central compartment $\left(\mathrm{V}_{\mathrm{c}}\right)$, apparent volume of distribution at steady state $\left(\mathrm{Vd}_{\mathrm{ss}}\right)$, total body clearance $\left(\mathrm{CL}_{\mathrm{B}}\right)$ and the bioavailability (F) were calculated by standard methods according to (Baggot, 1978 and Gibald and Perrier, 1982).

\section{Results}

Difloxacin is a fluoroquinolone having four florophenyl moieties, administered to camel at a dose of $5 \mathrm{mg} \mathrm{kg}^{-1}$ b.wt via i. v. and i. m. routes. The pharmacokinetic parameters after i.v. and i.m. administration are showed in (Table 1,2). The mean serum concentration time curves following i. v. and i. m. administration were depicted in (Fig. 1).

The results of the present study revealed that serum concentration of difloxacin following i.v. injection in camel was best fitted with two comparetement open model. Difloxacin was rapidly distributed after i.v. administration indicated by short distribution half life $\left(\mathrm{t}_{0.5}(\alpha)\right.$ $0.513 \pm 0.01 \mathrm{~h}$ and $\mathrm{K} 120.676 \pm 0.058 \mathrm{~h}$. The drug was slowly eliminated with $\mathrm{t}_{0.5 \text { ( } \beta \text { ) }} 6.30 \pm$ $0.75 \mathrm{~h}$, total body clearance $\left(\mathrm{Cl}_{\mathrm{B}}\right) 0.141 \pm 0.0311$ $\mathrm{kg}^{-1} \mathrm{~h}^{-1}$ and volume of distribution $1.10 \pm 0.0351$ $\mathrm{kg}^{-1}$.

After intramuscular injection, difloxacin was absorbed with $\mathrm{t}_{0.5 \text { (ab) }} 0.95 \pm 0.003 \mathrm{~h}$ and slowly eliminated with $\mathrm{t}_{0.5}$ (el) $5.86 \pm 0.33 \mathrm{~h}$. The maximum serum concentration was $2.59 \pm 0.19$ ug $\mathrm{ml}^{-1}$ achieved after $\mathrm{T}_{\max }$ of $3.05 \pm 0.035 \mathrm{~h}$. The mean absorption time (MAT) after i. m administration of difloxacin was $2.14 \pm 0.135 \mathrm{~h}$. The systemic bioavailability after i. m. administration was $87.95 \%$ and serum protein binding tendency was $23 \%$.
Table (1): Mean ( \pm SE) kinetic parameters of difloxacin following intravenous administration of $5 \mathrm{mg} \mathrm{kg}^{-1} \mathrm{~b}$. wt. in camel $(\mathrm{n}=3)$.

\begin{tabular}{|c|c|c|}
\hline Parameter & Unit & Mean \pm SE \\
\hline $\mathbf{C} \mathbf{p}^{0}$ & ug ml$l^{-1}$ & $11.27 \pm 2.5$ \\
\hline B & ug $\mathrm{ml}^{-1}$ & $3.25 \pm 0.26$ \\
\hline$\beta$ & $\mathrm{h}^{-1}$ & $0.11 \pm 0.01$ \\
\hline$t_{0.5(\beta)}$ & $\mathrm{h}$ & $6.30 \pm 0.15$ \\
\hline A & ug ml$l^{-1}$ & $8.01 \pm 1.95$ \\
\hline$\alpha$ & $\mathrm{h}^{-1}$ & $1.35 \pm 0.25$ \\
\hline $\mathbf{t}_{0.5(\alpha)}$ & $\mathrm{h}$ & $0.513 \pm 0.01$ \\
\hline $\mathbf{k}_{12}$ & $h^{-1}$ & $0.676 \pm 0.17$ \\
\hline$k_{21}$ & $h^{-1}$ & $0.469 \pm 0.12$ \\
\hline $\mathbf{k}_{\mathrm{el}}$ & $\mathrm{h}^{-1}$ & $0.318 \pm 0.02$ \\
\hline Vc & $1 \mathrm{~kg}^{-1}$ & $0.444 \pm 0.01$ \\
\hline $\mathbf{V} d_{\mathrm{ss}}$ & $1 \mathrm{~kg}^{-1}$ & $1.100 \pm 0.035$ \\
\hline $\mathrm{Cl}_{\mathrm{B}}$ & $1 \mathrm{~kg}^{-1} \mathrm{~h}^{-1}$ & $0.141 \pm 0.01$ \\
\hline AUC & ug $\mathrm{ml}^{-1} \mathrm{~h}^{-1}$ & $35.38 \pm 3.72$ \\
\hline AUMC & ug $\mathrm{ml}^{-1} \mathrm{~h}^{-1}$ & $272.7 \pm 19.72$ \\
\hline MRT & $\mathrm{h}$ & $7.69 \pm 3.2$ \\
\hline
\end{tabular}

Table (2): Mean (+ SE) Kinetic parameters of difloxacin following intramusclar administration of $5 \mathrm{mg} \mathrm{kg}^{-1}$ b.wt. in camel $(\mathrm{n}=3)$.

\begin{tabular}{ccc}
\hline Parameter & Unit & Mean \pm SE \\
\hline $\mathbf{A}$ & ug ml $^{-1}$ & $4.390 \pm 2.53$ \\
$\mathbf{k}_{\mathbf{a b}}$ & $\mathrm{h}^{-1}$ & $0.728 \pm 0.41$ \\
$\mathbf{t}_{\mathbf{0 . 5}}$ & $\mathrm{h}$ & $0.950 \pm 0.003$ \\
$\mathbf{B}$ & $\mathrm{ug} \mathrm{ml}^{-1}$ & $4.390 \pm 0.96$ \\
$\mathbf{K}_{\text {el }}$ & $\mathrm{h}^{-1}$ & $0.118 \pm 0.01$ \\
$\mathbf{t}_{\mathbf{0 . 5}}$ & $\mathrm{h}$ & $5.860 \pm 0.33$ \\
$\mathbf{C}_{\mathbf{m a x}}$ & $\mathrm{ug} \mathrm{ml}^{-1}$ & $2.590 \pm 0.19$ \\
$\mathbf{T}_{\mathbf{m a x}}$ & $\mathrm{h}$ & $3.050 \pm 0.035$ \\
$\mathbf{A U C}$ & $\mathrm{ug} \mathrm{ml}^{-1} \mathrm{~h}^{-1}$ & $31.119 \pm 2.95$ \\
AUMC & $\mathrm{ug} \mathrm{ml}^{-1} \mathrm{~h}^{-1}$ & $305.96 \pm 23.4$ \\
MRT & $\mathrm{h}$ & $9.830 \pm 0.49$ \\
MAT & $\mathrm{h}$ & $2.140 \pm 0.135$ \\
$\mathbf{F}$ & $\%$ & $87.95 \pm 5.33$ \\
\hline
\end{tabular}

* Protein binding $23 \%$

\section{Discussion}

Interpretation of results of the present study takes into consideration the assay method used (microbiological) and its sensitivity. The bioassay method did not, however distinguish between the parent drug (difloxacin) and its active metabolite (sarafloxacin). The presence of active metabolite may not necessarily interfere with determination of a therapeutic dosage regimen (Gavrielli et al., 1995). In general, fluoroquinolones are well tolerated drugs having little adverse effects compared with many other classes of antibacterials (Wolfson and Hooper, 1991)

The concentration time course of difloxacin in serum of camel following i. v. administration $5 \mathrm{mg} \mathrm{kg}^{-1}$ b.wt. was best described by two com- 

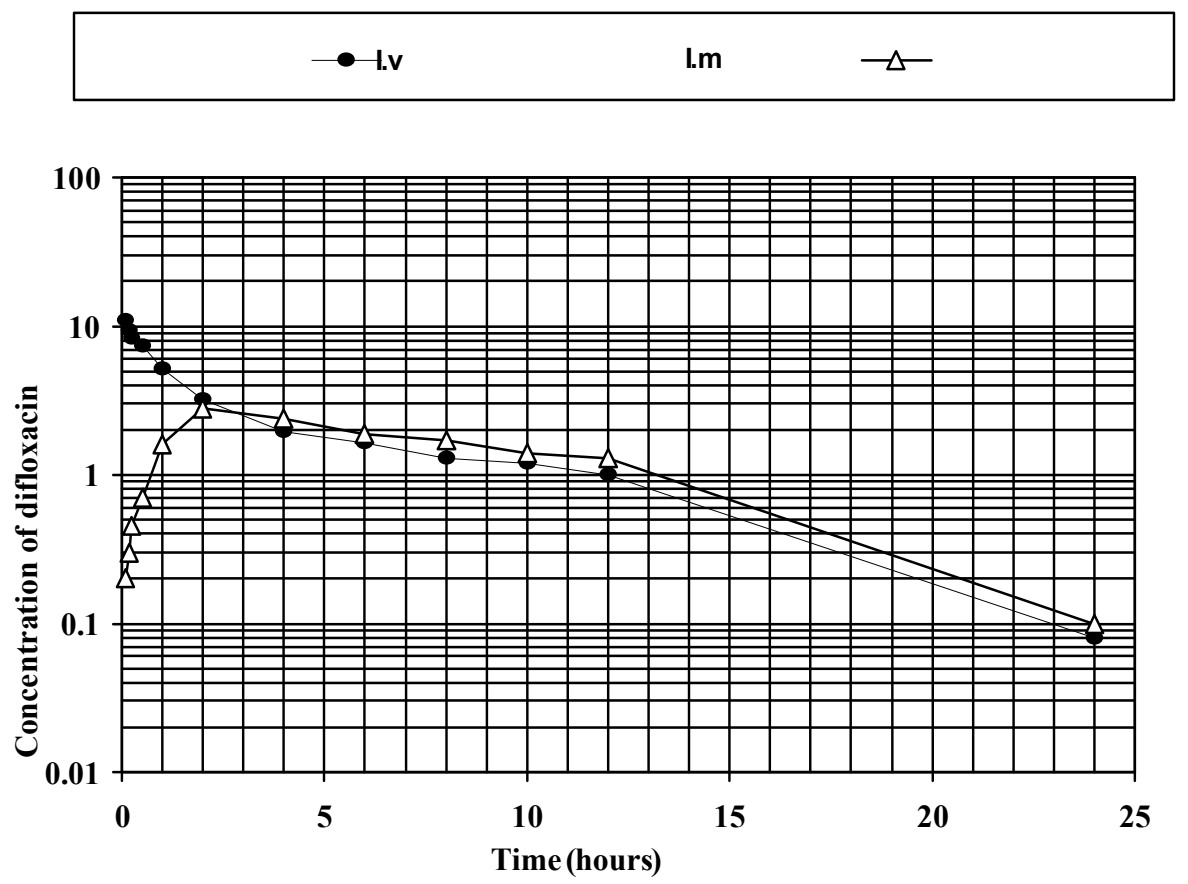

Fig. (1): Semilogarithmic graph depicting the timeoncentration of difloxacin in serum of camel after a single intravenous and intramuscular injection of $5 \mathrm{mg} \mathrm{kg-1} \mathrm{b.wt.}$

partment open model. This is consistent with finding reported for difloxacin in chicken and pig (Inui et al., 1998) and goat (Atef et al., 2002).

Difloxacin was rapidly distributed with a distribution half life $\left(\mathrm{t}_{0.5(\alpha)}\right)$ of $0.513 \mathrm{~h}$, which is similar to findings reported in pigs $0.50 \mathrm{~h}$ and chickens 0.66 h (Inui et al., 1998). Difloxacin administered i. v. to camels was eliminated slowly with a half-life $\left(\mathrm{t}_{0.5(\beta)}\right) 6.30 \mathrm{~h}$. This halflife is relatively similar to that reported in goats $6.30 \mathrm{~h}$ (Atef et al., 2002), and is larger than the values calculated for the drug in chickens $4.10 \mathrm{~h}$ (Inui et al., 1998), and in rabbits $3.25 \mathrm{~h}$ (Abd EL-Aty et al., 2005), and for danofloxacin in camels $5.37 \mathrm{~h}$ (Ali abadi et al., 2003), enrofloxacin in rabbits $2.5 \mathrm{~h}$ (Broome et al., 1991) and for ofloxacin in rabbits 1.5-1.6 h (Marangos et al., 1997).

The volume of distribution at steady-state (Vdss) is an accurate indication of the diffusion of the drug into the body tissues (Galinsky and Svensson, 1995). The distribution of difloxacin in the body of camels is large (Vdss) of 1.101 $\mathrm{kg}^{-1}$. This value indicates that the drug is widely distributed into extravascular tissues. Similar results were previously reported for difloxacin in pigs $1.71 \mathrm{~kg}^{-1}$ (Inui et al., 1998), goats $1.11 \mathrm{~kg}^{-1}$ (Atef et al., 2002) and rabbit $1.511 \mathrm{~kg}^{-1}$ (Abd ElAty et al., 2005), but was smaller than value reported in chickens $3.06 \mathrm{l} \mathrm{kg}^{-1}$ (Inui et al., 1998). The total body clearance of difloxacin in this study is $0.141 \mathrm{l} \mathrm{kg}^{-1} \mathrm{~h}^{-1}$, similar to value reported in goats of $0.131 \mathrm{~kg}^{-1} \mathrm{~h}^{-1}$ (Atef et al., 2002), but lower than finding in rabbit $0.591 \mathrm{~kg}^{-}$ ${ }^{1} \mathrm{~h}^{-1}$ (Abd El Aty et al., 2005) and danofloxacin in camel $0.441 \mathrm{~kg}^{-1} \mathrm{~h}^{-1}$ (Ali abadi et al., 2003).

Differences in kinetic parameters are relatively common and are frequently related to interspecies variation, age, breed, health status of the animals and/or the assay method used (Haddad et al., 1985).

Difloxacin was absorbed from the site of i. $\mathrm{m}$ injection with absorption half-life $\left(\mathrm{t}_{0.5}(\mathrm{ab})\right) 0.95 \mathrm{~h}$. The peak plasma concentration and the duration for which the quinolone concentration remains greater than the minimum inhibitory concentration (MIC) of the susceptible microorganisms 
have been shown to be predicttive of the therapeutic success (Peloquin et al., 1989). The peak plasma concentration (Cmax) of difloxacin (2.59 ug $\mathrm{ml}^{-1}$ ) was attained $3.05 \mathrm{~h}$ after adminis-tration

of the drug. These values differ from those observed following the same route in rabbit 3.85 ug $\mathrm{ml}^{-1}$ at $1.61 \mathrm{~h}$ (Abd El-Aty et al., 2005) and in goats $4.1 \mathrm{ug} \mathrm{ml}^{-1}$ at $1 \mathrm{~h}$ (Atef et al., 2002), and following the oral route in pig $3.61 \mathrm{ug} \mathrm{ml}^{-1}$ at $1.25 \mathrm{~h}^{2}$ and chickens $0.96 \mathrm{ug} \mathrm{m}^{-1}$ at $1.40 \mathrm{~h}$ (Inui et al., 1998) and in dogs $1.79 \mathrm{ug} \mathrm{ml}^{-1}$ at $2.17 \mathrm{~h}$ (Frazier et al., 2000) and $1.11 \mathrm{ug} \mathrm{ml}^{-1}$ at $2.84 \mathrm{~h}$ (Heinen, 2002). This difference might be due to species differences, route of administer-ation and/or the used assay method.

Following i. $\mathrm{m}$ administration, the elimination half-life $\left(\mathrm{t}_{0.5 \text { (el) }}\right)$ was $5.86 \mathrm{~h}$. This value is similar to that reported for danofloxacin in camel 5.71 h., (Ali abadi et al., 2003), but larger than that in rabbit $3.82 \mathrm{~h}$ (Abd El Aty et al., 2005) and smaller than after the oral route in chickens $7.35 \mathrm{~h}$ (Inui et al., 1998), dogs $8.52 \mathrm{~h}$ (Frazier et al., 2000) and $6.9 \mathrm{~h}$ (Heinen, 2002). Variability in elimination half-life of difloxacin after i. $\mathrm{m}$ administration might be due to species variation, route of administration and/or the used assay method.

The in vitro protein binding tendency of difloxacin to plasma proteins was $23 \%$. This indicated that the drug is slightly bound to proteins. This is similar to value previously reported in rabbit $21.45 \%$ (Abd El-Aty et al., 2005) but differs from the values reported in goats $13.79 \%$ (Atef et al., 2002) and human 46$52 \%$ (Granneman et al., 1986).

The bioavailability $(\mathrm{F})$ of difloxacin after $\mathrm{i}$. $\mathrm{m}$ administration in camels was $87.95 \%$. This value similar to that is previously reported in chickens $86.9 \%$ (Inui et al., 1998), but slightly lower than in pigs $93.7 \%$ (Inui et al., 1998), goats $95.4 \%$ (Atef et al., 2002) and rabbit 95.29 $\%$ (Abd El-Aty et al., 2005). Variability in absorption from the i. $\mathrm{m}$ site might be due to differences in regional blood flow in the different muscle tissue sites which is the major determinant.

Our results indicated that difloxacin can be detected for $24 \mathrm{~h}$ in plasma following a single $\mathrm{i}$. $\mathrm{v}$ and/or $\mathrm{i}$. $\mathrm{m}$ administration in camels. The concentrations exceeded the MICs for various sensitive bacteria. Enterobacteriaceae are the most commonly isolated organisms from urinary tract infections (Lees and Forester, 1992). Fluoroquinolones have low MIC values against many Gram-negative bacteria (Prescott and Baggot, 1993), they have therefore become popular in the treatment of Gram-negative infections in different animal species. The MIC of difloxacin against E. coli was $0.12 \mathrm{ug} \mathrm{ml}^{-1}$ (Fernandes et al., 1986), 0.03-0.2 ug ml (Stamm et al., 1986), 0.125-0.5 ug ml ${ }^{-1}$ (Hardy et al., 1987) and $0.065 \mathrm{ug} \mathrm{ml}^{-1}$ (Abd El-Aty et al., 2005).

Based on MIC data previously mentioned and on our results, we concluded that daily dose of $5 \mathrm{mg} \mathrm{kg}^{-1}$ b.wt. would be an adequate dosage in $E$. coli infected camels.

\section{References}

Abd El-Aty, A. M.; Goudah, A.; Ismail, M. and Shimoda, M. (2005): Disposition kinetics of difloxacin in rabbit after intravenous and intramuscular injection of dicural. Vet. Res. Comm., 29: 297-304.

Adams, H. R. (1995): Veterinary Pharmacology and Therapeutics $7^{\text {th }}$ ed.

Ali abadi, F. S.; Ali, B. H.; Landoni, M. F. and Lees, P. (2003): Pharmacokinetics and PK-PD modeling of danofloxacin in camel serum and tissue cage fluids. Vet. J., 165: 104-118.

Atef, M.; El-Banna, H. A.; Abd El-Aty, A. M. and Goudah, A. (2002): Pharmacokinetics of difloxacin in goats. Deutsche Tierarztliche Wochenschrift, 109: 320-323. Baggot, J. D. (1977): principles of drug disposition in domestic animals: The basis of veterinary clinical pharmacology, $1^{\text {st }}$ ed. pp.144-189. W. B. saunders, Philadelphia,USA.

Baggot, J. D. (1978): Some spects of clinical pharmacokinetics in veterinary medicine. J. Vet. Pharmacol. Ther., 1: 5-17.

Bennet, N.; Jean, L.; Brodie, Ernest, J., Benner and William, M. (1966): Simplified, accurate method for antibiotic assay of clinical specimens. Appl. Microbiol., 14 (2): 170-177.

Broome, R. L.; Brooks, D. L.; Babish, J. G., D. D. and Conzelman, G.M. (1991): Pharmacokinetic properties of enrofloxacin in rabbits. American J. Vet. Res., 52: 18351841.

Craig, A. W. and Suh, B. (1980): Protein binding and the antibacterial effects: Methods for determination of protein binding. In: V. Lorian (ed.), Antibiotics in Laboratory Medicine, (Williams and Wilkins, Baltimore, MD), 265297.

Etzion, Z. and Yagil, R. (1986): Renal function in camels (camelus dromedaries) following rapid rehydration. Physiologica et Zoologica, 59,558-562.

Fernandes, P. B.; Chu, D. T. W.; Bower, R. R.; Jarvis, K. P.; Ramer, N. R. and Shipkowitz, N. (1986): In vivo evaluation of A-56619 (difloxacin) and A-56620: new arylflouroquinolones. Antimicrob. Agents Chem., 29: 201-208.

Frazier, D. L.; Thompson, L.; Trettien, A. and Evans, E. I. (2000): Comparison of fluoroquinolone pharmacokinetic parameters after treatment with marbofloxacin, enrofloxacin and difloxacin in dogs. J. Vet. Pharmacol. Therap., 23: 293-302.

Galinsky, R. E. and Svensson, C. K. (1995): Basic pharmacokinetics. In: J.P. Remington (ed.), the science and Practice of Pharmacy, $19^{\text {th }}$ ed., (Mack Publishing Company, Easton, PA), pp.724-740. 
Gavrielli, R.; Yagil, R.; Ziv, G.; Creveld, C. and Glickman, A. (1995): Effect of water deprivation on the disposition kinetics of enrofloxacin in camels. J. Vet. Pharmacol. Therap., 18: 333-339.

Gibaldi, M. and Perrier, D. (1982): Pharmacokinetics, $2^{\text {nd }}$ ed. Marcel Dedder, New York.

Granneman, G. R.; Snyder, K. M. and Suh, V. S. (1986): Difloxacin metabolism and pharmacokinetics in human after single oral doses. Antimicrob. Agents Chem., 30: 689693.

Haddad, N. S.; Pedersoli, W. M.; Ravis, W. R.; Fazeli, M. H. and Carson, R. L. Jr. (1985): Combined pharmacokinetics of gentamicin in pony mares after a single intravenous and intramuscular administration. Am. J. Vet. Res., 46: 2004-2007.

Hardy, D. J.; Swanson, R. N.; Hensey, D. M.; Ramer, N. R.; Bower, R. R.; Hanson, C. W.; Chu, D. T. W. and Fernandes, P.B. (1987): Comparative antibacterial activities of temofloxacin hydrochloride (A-62254) and two reference flouroquinolones. Antimicrob. Agents Chem., pp.1768-1774.

Heinen, E. (2002): Comparative serum pharmacokinetics of the fluoroquinolones enrofloxacin, difloxacin, marbofloxacin and orbifloxacin in dogs after single oral administration. J. Vet. Pharmacol. Therap., 25: 1-5.

Inui, T.; Taira, T.; Matsushita, T. and Endo, T. (1998): Pharmacokinetic properties and oral bioavailabilities of difloxacin in pig and chickens. Xenobiotica, 28: 887-893.

Lees, G. E. and Forester, S. D. (1992): Update: Bacterial urinary tract infection. Current Veterinary Therapy Vol. XI, Small Animal Practice, W. B. Saunders, Phila-delphia, PA. pp. 904-914.
Marangos, M. N.; Zhu, Z.; Nicolau, D. P.; Klepser, M. E. and Nightingale, C. H. (1997): Disposition of ofloxacin in female New Zealand White rabbits. J. Vet. Pharmacol Therap., 20: 17-20.

Oukessou, M.; Hossaini, J.; Zine-Filali, R. and Toutain, P. L. (1990): Comparative benzyl penicillin pharmacokinetics in dromedary camels (camelus dromedaries) and in sheep. J. Vet. Pharmacol. Therap., 13: 298-303.

Peloquin, C. A.; Cumbo, T. J.; Nix, D. E.; Sands, M. F. and Schentag, J. J. (1989): Evaluation of intravenous ciprofloxacin in patients with nosocomial lower respiratory tract infections: impact of plasma concentrations, organism MIC, and clinical condition on bacterial eradication. Arch. Inter. Med., 149: 2269-2273.

Prescott, J. F. and Baggot, J. D. (1993): Antimicrobial Therapy in Veterinary Medicine, $2^{\text {nd }}$ ed., (Iowa State Univ. Press, Ames, IA), pp.100-104.

Stamm, J .M.; Hanson, C. W.; Chu, D. T.; Bailer, R.; Vojtko, C. and Fernandes, P. B. (1986): In vitro evaluation of A-56619 (Difloxacin) A-56620: new arylfluoroquinolones. Antimicrob. Agents Chem., 29: 193-200.

Wolfson, J. S. and Hooper, D. C. (1991): Overview of fluoroquinolone safety. Am. J. Med., 91: 153S-161S.

Yagil, R. (1985): The desert camel. Comparative physiological adaptation. Karger Limited, Basel, pp. 19-42.

Yamaoka, K.; Nakagawa, T. and Uno, T. (1978): Statistical moments in pharmacokinetics. J. Pharmacokin. Biopharm., pp. 547-558.

Younan, W.; Nouws, J. F. M.; Homeida, A. M.; Vree, T. B. and Degen, M. (1989): pharmacokinetics and metabolism of sulpadimidine in the camel. J. Vet. Pharmacol. Therap., 12: 327-3 